\title{
Mechanical Behavior and Microstructure Evolution of Al-Cu-Li Alloy during Multi-Pass Hot Deformation
}

\author{
Yang Shengli, Shen Jian, Li Xiwu, Yan Xiaodong, Zhang Yongan, \\ Li Zhihui, Huang Shuhui, Xiong Baiqing
}

State Key Laboratory of Nonferrous Metals and Processes, General Research Institute for Nonferrous Metals, Beijing 100088, China

\begin{abstract}
Continuous, discontinuous, double-pass and multi-pass hot isothermal compression tests were conducted to understand the mechanical behavior and microstructure evolution of the $\mathrm{Al}-2.5 \mathrm{Cu}-1.58 \mathrm{Li}-0.3 \mathrm{Mn}-0.12 \mathrm{Zr}-0.06 \mathrm{Mg}-0.05 \mathrm{Ti}$ (wt $\%$ ) alloy. The tests were conducted at temperature of $420^{\circ} \mathrm{C}$ and strain rates of $0.001,0.1$ and $10 \mathrm{~s}^{-1}$ on Gleeble-1500. EBSD and TEM were used to investigate microstructure evolution at different deformation stages of the alloy. Double-pass hot deformation results show that the extension of interval time between two passes is conductive to promoting static softening. It is possible to control the grain size in the test alloy by changing the strain rate at different deformation stages. During multi-pass hot deformation process, static softening between the deformation pass is beneficial to the dynamic softening, vice versa. Dynamic precipitation of $\mathrm{T}_{1}$ and $\theta^{\prime}$ phase is observed during the multi-pass deformation process $\left(T=420{ }^{\circ} \mathrm{C}, \dot{\varepsilon}=0.1 \mathrm{~s}^{-1}\right)$. In the initial stage of multi-pass deformation, strain-induced dislocations provide the nucleation site for $\theta^{\prime}$ and $\mathrm{T}_{1}$ phase, promoting their precipitation and coarsening. With increasing of strain, the size of the precipitates $\mathrm{T}_{1}$ and $\theta^{\prime}$ phase decreases and then tends to be stable, and the density of $\delta^{\prime}$ phase decreases. Flow stress of the test alloy during multi-pass hot deformation is influenced by dynamic softening, static softening and dynamic precipitation.
\end{abstract}

Key words: flow stress; dynamic softening; static softening; dynamic precipitation

With the rapid development of the aerospace industry, $\mathrm{Al}-\mathrm{Cu}-\mathrm{Li}$ alloys are being extensively used for aerospace structures owing to their high stiffness to density ratio and large elastic modulus compared with conventional $2 \mathrm{xxx}$ and $7 \mathrm{xxx}$ series alloys ${ }^{[1]}$. Al- $\mathrm{Cu}-\mathrm{Li}$ alloy thick plate is the main component of the aircraft application. However, thermo -plastic range of $\mathrm{Al}-\mathrm{Cu}-\mathrm{Li}$ alloy is relatively narrow, which makes it at the risk of cracking during producing of the thick plate. Thermomechanical processing (TMP) parameters should be designed to control the microstructural evolution and subsequent mechanical properties of the final production ${ }^{[2]}$. A comprehensive study of hot deformation behavior and microstructure evolution of $\mathrm{Al}-\mathrm{Cu}-\mathrm{Li}$ alloys is of great importance. At present, the study on the hot deformation of Al-Cu-Li alloy is mainly focused on the construction of the constitutive model ${ }^{[3]}$, the processing map analysis ${ }^{[4,5]}$ and the heat treatment ${ }^{[6,7]}$. However, the research on the multi-pass hot deformation process of Al-Cu-Li alloy is less.

Multi-pass hot rolling is essential for the production of $\mathrm{Al}-\mathrm{Cu}-\mathrm{Li}$ alloy thick plate. During the successive deformation process of multi-pass hot rolling ${ }^{[8]}$, hardening and dynamic softening exist simultaneously because dynamic recovery $(\mathrm{DRV})^{[9]}$, dynamic recrystallization $(\mathrm{DRX})^{[10]}$ and precipitation and dissolution of the second phase $^{[11,12]}$ are inevitable. But, multi-pass hot rolling process is discontinuous. During the inter-pass periods, the alloys will subject to the static recovery (SRV), metadynamic recrystallization and static recrystallization $(\mathrm{SRX})^{[8]}$. Meanwhile, the microstructure and properties of the alloy are influenced by complex time, strain, strain rate and temperature history during industrial deformation processes $^{[13]}$. During the multi-pass hot deformation process, on the one hand, microstructure evolution is determined at a

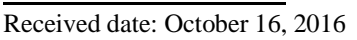

Foundation item: National Natural Science Foundation of China (51274046)

Corresponding author: Yang Shengli, Candidate for Ph. D., State Key Laboratory of Nonferrous Metals and Processes, General Research Institute for Nonferrous Metals, Beijing 100088, P. R. China, Tel: 0086-10-82241172, E-mail: bravictors@126.com 
given hot deformation conditions. On the other hand, microstructure evolution of alloy in turn affects the mechanical characteristics of the alloy such as the flow stress, and influences the deformation process ${ }^{[14]}$. Hence, the relationship between the flow behavior and microstructure evolution of $\mathrm{Al}-\mathrm{Cu}-\mathrm{Li}$ alloy during multi-pass deformation is very complex.

In this study, the flow behavior of Al-Cu-Li alloy was investigated by continuous, discontinuous, double-pass and multi-pass hot compression tests. The corresponding microstructure evolution was investigated by EBSD and TEM analysis.

\section{Experiment}

The chemical composition of the test alloy in this work was composed of $2.5 \mathrm{Cu}, 1.58 \mathrm{Li}, 0.3 \mathrm{Mn}, 0.12 \mathrm{Zr}, 0.06 \mathrm{Mg}$, $0.05 \mathrm{Ti}$, and Al-Bal. (wt \%). The cast ingot was homogenized at $460{ }^{\circ} \mathrm{C}$ for $20 \mathrm{~h}$ followed by $525{ }^{\circ} \mathrm{C}$ for $24 \mathrm{~h}$ and then cooled down to room temperature in air. Cylindrical specimens of $10 \mathrm{~mm}$ in diameter and $15 \mathrm{~mm}$ in height were machined from it for compression tests. Graphite sheet was used between the specimens for reducing the deformed friction. The specimens were heated with a rate $5{ }^{\circ} \mathrm{C} / \mathrm{s}$ and held for $3 \mathrm{~min}$ at the deformation temperatures in order to establish a uniform temperature prior to deformation. Continuous, discontinuous, double-pass and multi-pass hot compression tests were carried out on Gleeble-1500 at temperature of $420{ }^{\circ} \mathrm{C}$, strain rates of $0.001,0.1,10 \mathrm{~s}^{-1}$, because $420{ }^{\circ} \mathrm{C}$ is the hot rolling parameter for the industrial production of the test materials. In order to investigate microstructural evolution of the deformed specimen, the specimens were immediately quenched in water after deformed. The specimens were polished in an electrolyte composed of $10 \mathrm{~mL} \mathrm{HClO}_{4}$ and $90 \mathrm{~mL}$ methanol ethanol at voltage of $20 \mathrm{~V}$ for $10 \mathrm{~s}$. Then, the specimens were analyzed using a SEM equipped with an EBSD system to determine the morphologies. TEM films were prepared by the conventional method: $0.5 \mathrm{~mm}$ thick foils were cut from the deformed specimens. Then the thick foils were ground into $0.05 \mathrm{~mm}$ and disks with $3 \mathrm{~mm}$ in diameter were punched out from these foils, and subsequently two-jet thinned in a solution of $75 \mathrm{~mL} \mathrm{HNO}_{3}$ and $225 \mathrm{~mL}$ methanol cooled to -30 ${ }^{\circ} \mathrm{C}$. TEM microstructure was investigated by TecnaiG20.

\section{Results and Discussion}

\subsection{Double-pass hot deformation}

Fig.1a shows flow stress curves for Al-Cu-Li alloy under isothermal double-pass deformation at $420{ }^{\circ} \mathrm{C}$ and strain rate of $0.1 \mathrm{~s}^{-1}$. For all the deformation conditions, the stress-strain curves rapidly reach a peak stress at a small strain, after which the flow stresses decrease monotonously and a typical multi-peak appears due to $\mathrm{DRX}^{[15]}$. In the early stage of deformation, strain-induced dislocation density sharply increases, increasing the flow stress. DRX occurs when the strain exceeds the critical strain ${ }^{[16]}$. Flow stress of the second pass decreases with the extension of interval time at the same deformation parameters, indicating that static softening occurs in the inter-stage duration. In the present study, the $0.2 \%$ offset yield stress ${ }^{[17]}$ is used to determine the static softening behavior, as shown in Fig.1b. Fraction softening increases from $25.7 \%$ to $36.4 \%$ with increasing interval time from $5 \mathrm{~s}$ to $30 \mathrm{~s}$. Kwon $^{[18]}$ reported that static softening is related to fractional recrystallization in a nonlinear relationship, and the degree of nonlinearity is closely dependent on the emergence of recovery and recrystallization.

Fig.2 shows the effect of continuous and discontinuous strain rate on flow stress during hot deformation process. The initial flow curves with the same strain rate, strain of 0.35 , are almost the same, but a little difference is observed due to microstructural inhomogeneity among samples or experimental errors. As shown in Fig.2, when the strain rate is continuous $\left(0.001 \mathrm{~s}^{-1}\right.$ or $\left.10 \mathrm{~s}^{-1}\right)$, flow stress increases quickly to a peak value and then tends to a stable value with increasing of strain. However, flow stress develops after strain rate change increases (from $0.001 \mathrm{~s}^{-1}$ to $10 \mathrm{~s}^{-1}$ ) or decreases (from $10 \mathrm{~s}^{-1}$ to $0.001 \mathrm{~s}^{-1}$ ) and approaches a new stable value. It is worth noting that the new stable value after increasing or decreasing strain rate (from $0.001 \mathrm{~s}^{-1}$ to $10 \mathrm{~s}^{-1}$, or from $10 \mathrm{~s}^{-1}$ to $0.001 \mathrm{~s}^{-1}$ ) becomes lower than at a continuous strain rate $10 \mathrm{~s}^{-1}$ or $0.001 \mathrm{~s}^{-1}$. Besides, the difference between them increases with increasing in strain.
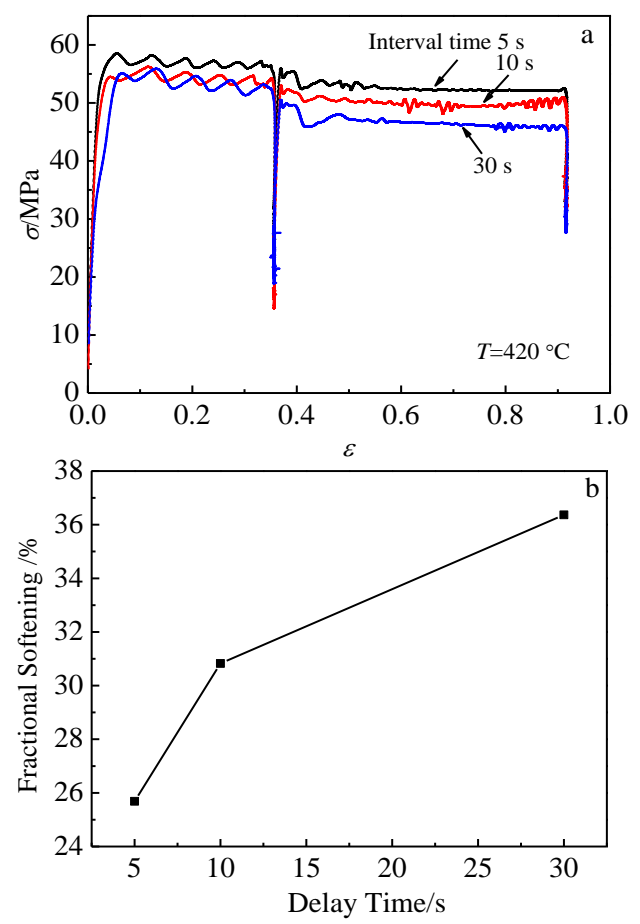

Fig.1 Stress-strain curves of the test alloy in double-pass hot deformation (a) and corresponding fractional softening (b) 


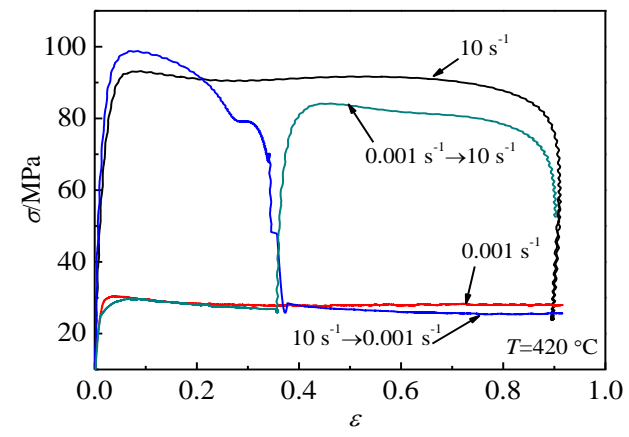

Fig.2 Effect of continuous and discontinuous strain rate on flow stress during hot deformation process $\left(T=420^{\circ} \mathrm{C}\right)$

Fig.3 shows the EBSD images of $\mathrm{Al}-\mathrm{Cu}-\mathrm{Li}$ alloy deformation at continuous and discontinuous strain rate corresponding to Fig.2, together with an imaging quality (IQ) map (insert the top right corner). As shown in Fig.3a, at continuous strain rate of $10 \mathrm{~s}^{-1}(\varepsilon=0.92)$, adiabatic shear heat cannot easily disperse in time due to high strain rate and low thermal conductivity, inducing flow localizations along the maximum shear stress direction, causing the formation of micro-shear bands crossing a grain interior. A large amount of fine sub-grains are generated in the micro-shear bands, as presented in Fig.3a IQ image. At continuous strain rate of $0.001 \mathrm{~s}^{-1}(\varepsilon=0.92)$, DRX occurs near the grain boundaries which are shown in white arrows in Fig.3b, where new DRX grains are surrounded by blue high angle boundary (HAB: $\geqslant$ $15^{\circ}$ ). Sufficient time is available for DRV and DRX at the lower strain rate. As a result, the movement and gathering of dislocations near the grain boundaries provide sufficient impetus for DRX. As seen from Fig.3c and 3d, with discontinuous strain rate of $0.001 \mathrm{~s}^{-1} \rightarrow 10 \mathrm{~s}^{-1}$, DRV is sufficient at the low strain rate stage, causing shortage of storage energy for DRX in the subsequent high strain rate stage. Hence, DRX is not obvious in Fig.3d. However, some DRX nuclei already form during the preceding low strain rate range deformation. It is beneficial to the DRX due to lacking of an incubation time for grain nucleation at later stage, resulting in the slight increasing of $\mathrm{HAB}$ fraction from $20.9 \%$ to $23.8 \%$ (Fig.3c, 3d) and the decreasing of flow stress (Fig.2). Fig.3e and $3 \mathrm{f}$ represents the EBSD images of the test alloy deformed at discontinuous strain rate of $10 \mathrm{~s}^{-1} \rightarrow 0.001$ $\mathrm{s}^{-1}$, respectively. Few low angle boundary $\left(\mathrm{LAB}:<15^{\circ}=\right.$ are formed in the grain interiors after deformation at the strain rate of $10 \mathrm{~s}^{-1}(\varepsilon=0.36)$, as shown in Fig.3e. As the deformation continues at a strain rate of $0.001 \mathrm{~s}^{-1}(\varepsilon=0.92)$, the deformed grains are almost completely replaced by small equiaxed new DRX grains with HAB and sub-grains boundaries with LAB, as shown in the top right corner of Fig.3f. HAB fraction increases from $24.7 \%$ to $32.5 \%$. Enough driving force provided by deformation at high strain rate is available for the DRX during the subsequent low strain rate deformation process. Fig. 3 indicates that the strain rate clearly affects the DRX process of the $\mathrm{Al}-\mathrm{Cu}-\mathrm{Li}$ alloy during the high-temperature deformation. It is possible to control the grain size of $\mathrm{Al}-\mathrm{Cu}-\mathrm{Li}$ alloy by changing the strain rate at different deformation stages. For instance, as shown in Table.1, at continuous strain rate of $10 \mathrm{~s}^{-1}(\varepsilon=0.92)$ or 0.001 $\mathrm{s}^{-1}(\varepsilon=0.92)$, the average grain size of the alloy is $298.5 \mu \mathrm{m}$ and $316.1 \mu \mathrm{m}$, respectively. However, when the strain rate is discontinuous $\left(0.001 \mathrm{~s}^{-1} \rightarrow 10 \mathrm{~s}^{-1}\right.$ or $\left.10 \mathrm{~s}^{-1} \rightarrow 0.001 \mathrm{~s}^{-1}\right)$, the average grain size of the alloy is $312.8 \mu \mathrm{m}$ and $108.8 \mu \mathrm{m}$, respectively. That is, the grain can be significantly refined when the alloy deformed at low strain rate after high strain rate.

\subsection{Multi-pass hot deformation}

Fig.4 shows that stress-strain curves of multi-pass (interval time $5 \mathrm{~s} / 4 \mathrm{~s} / 3 \mathrm{~s} / 2 \mathrm{~s}$ ) between the deformation pass and single-pass continuous hot deformation with a strain rate of $0.1 \mathrm{~s}^{-1}$ at $420{ }^{\circ} \mathrm{C}$ to strain of 1.2. The flow stress of the alloy with multi-pass deformation is lower than that of single pass continuous deformation. However, the difference between them decreases with increasing in strain. Another phenomenon observed in Fig.4 is that flow stress decreases suddenly at the second pass hot deformation after holding five seconds at $420{ }^{\circ} \mathrm{C}$. Afterwards, flow stress gradually increases with increasing of the strain. Fig.5 shows the TEM images of the sample corresponding to different stages of multi-pass hot deformation in Fig.4. It can be seen from Fig.5a that cell structures are bounded by dislocation clusters. After five seconds of holding time at $420{ }^{\circ} \mathrm{C}$, dislocation of opposite sign are annihilated by cross-slip of screw dislocation and climb of edge dislocation forming low energy dislocation wall, as shown in Fig.5b. Fig.5c shows that sub-grains form in deformed original grains after the second pass deformation. But, some dislocations are pinned by some second phase. Fig.5d presents that dislocations separate from the second phase particles and then move to sub-grains boundaries during the interval of deformation pass. Above these results show obvious DRV and SRV characteristics. With the increase of strain, strain-induced dislocations will continuously increase and rearrange due to DRV and SRV. This will promote the formation of sub-grains, which is conductive to the formation of the DRX grains in the subsequent deformation stage for reducing the nucleation stage of DRX When the strain increases to 0.85 and held for three seconds between the deformation pass, as shown in Fig.5e, grains with clean and straight high-angle grain boundaries form, showing typical characteristics of DRX. In addition, the triple-junction grain boundaries can be seen in Fig.5e. Continue to increase the strain, sub-grains form in 

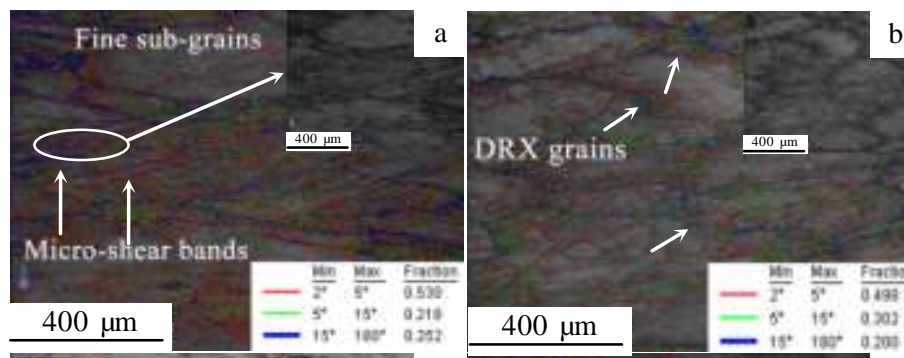

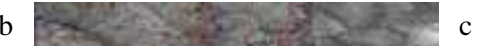
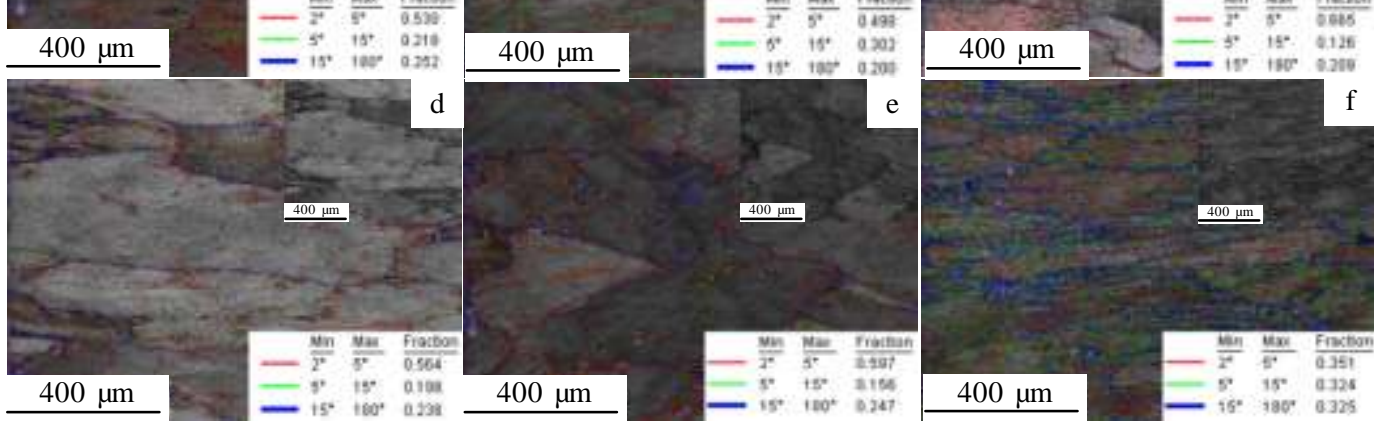

Fig.3 EBSD images of the test alloy deformed at continuous and discontinuous strain rate corresponding to Fig.2: (a) $10 \mathrm{~s}^{-1}(\varepsilon=0.92)$; (b) $0.001 \mathrm{~s}^{-1}(\varepsilon=0.92)$; (c) $0.001 \mathrm{~s}^{-1}(\varepsilon=0.36)$; (d) $0.001 \mathrm{~s}^{-1} \rightarrow 10 \mathrm{~s}^{-1}(\varepsilon=0.92)$; (e) $10 \mathrm{~s}^{-1}$ ( $\varepsilon=0.36$ ); (f) $10 \mathrm{~s}^{-1} \rightarrow 0.001 \mathrm{~s}^{-1}(\varepsilon=0.92$ ); ( $T=420{ }^{\circ} \mathrm{C}$, top right corner is the corresponding imaging quality map (IQ))

Table 1 Statistics of grain size in the corresponding Fig.3

\begin{tabular}{ccccc}
\hline Stage & $\mathrm{a}$ & $\mathrm{b}$ & $\mathrm{e}$ & $\mathrm{f}$ \\
\hline \multirow{2}{*}{ Grain size $/ \mu \mathrm{m}$} & 298.5 & 316.1 & 312.8 & 108.8 \\
\hline
\end{tabular}

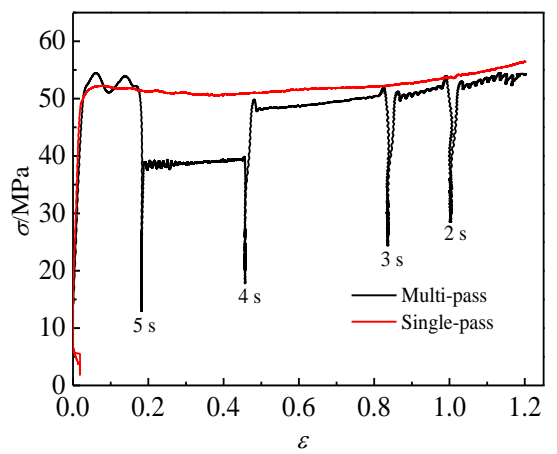

Fig.4 Stress-strain curves of the test alloy with multi-pass and single-pass hot deformation $\left(T=420^{\circ} \mathrm{C}, \quad \dot{\varepsilon}=0.1 \mathrm{~s}^{-1}\right)$

the deformed original grains and new DRX grains, as shown in Fig.5f. It can be concluded that the static softening between the deformation pass is beneficial to the dynamic softening, vice versa.

Fig.6 shows the STEM images and selected area electro diffraction (SAED) pattern along the $[110]_{\mathrm{Al}}$ axis of the original sample without compression and deformed sample corresponding to different stages of multi-pass hot deformation in Fig. $4\left(T=420{ }^{\circ} \mathrm{C}, \dot{\varepsilon}=0.1 \mathrm{~s}^{-1}\right)$. Fig.6a shows the STEM images and SAED pattern of the original sample homogenized at $460{ }^{\circ} \mathrm{C} / 20 \mathrm{~h}$ followed by $525^{\circ} \mathrm{C} / 24 \mathrm{~h}$ and then cooled in air. The superlattice spots in the rhombus center reveal the existence of the $\delta^{\prime}$ phase $\left(\mathrm{Al}_{3} \mathrm{Li}\right) . \delta^{\prime}$ phase (grey dot in Fig.6a) is full of whole grain, which indicates it is precipitated in the homogenization stage. In the grain boundary, there exist some large sized massive particles (labeled with ' $A$ '), which cannot be dissolved in the homogenization stage. EDS analysis confirms these particles as compounds of $\mathrm{Al}-\mathrm{Cu}-\mathrm{Mn}-\mathrm{Fe}$, as shown in Table.2. It can be seen from Fig.6b that the other two kinds of precipitates $\left(\theta^{\prime}-\mathrm{Al}_{2} \mathrm{Cu}, \mathrm{T}_{1}-\mathrm{Al}_{2} \mathrm{CuLi}\right)$ can be identified for the test alloy. They are labeled and marked with black arrows in Fig.6b. As can be seen from the SAED pattern in Fig.6b, the streaking in the [100] direction indicates the presence of the $\theta^{\prime}$ phase, the sports that located in the $1 / 3$ and $2 / 3$ positions of the long diagonal of the rhombus verifies the existence of the $T_{1}$ phase ${ }^{[6]}$. No evidence of $T_{1}$ and $\theta^{\prime}$ phase is found in the original sample, indicating that the two phases are precipitated during the hot compression process. As the multi-pass deformation continues, the density of $\delta^{\prime}$ phase decreases (Fig. $6 \mathrm{a} \sim 6 \mathrm{~g}$ ), and the size of $\theta^{\prime}$ and $\mathrm{T}_{1}$ decreases then tend to be stable (Fig.6b $\sim 6 \mathrm{~g}$ ).

$\delta^{\prime}, \mathrm{T}_{1}$ and $\theta^{\prime}$ phase are regarded as the major strengthening phase of $\mathrm{Al}-\mathrm{Cu}-\mathrm{Li}$ alloy. $\mathrm{T}_{1}$ phase is more inclined to precipitate near dislocation and grain boundaries by a stacking-fault mechanism ${ }^{[19]}$. In this study, flow behavior of multi-pass hot deformation is closely related to the microstructural evolution and dynamic precipitation. After the first pass deformation, a large number of strain-induced dislocations provide the nucleation site for $\theta^{\prime}$ and $\mathrm{T}_{1}$ phase, leading to their precipitation and coarsening 


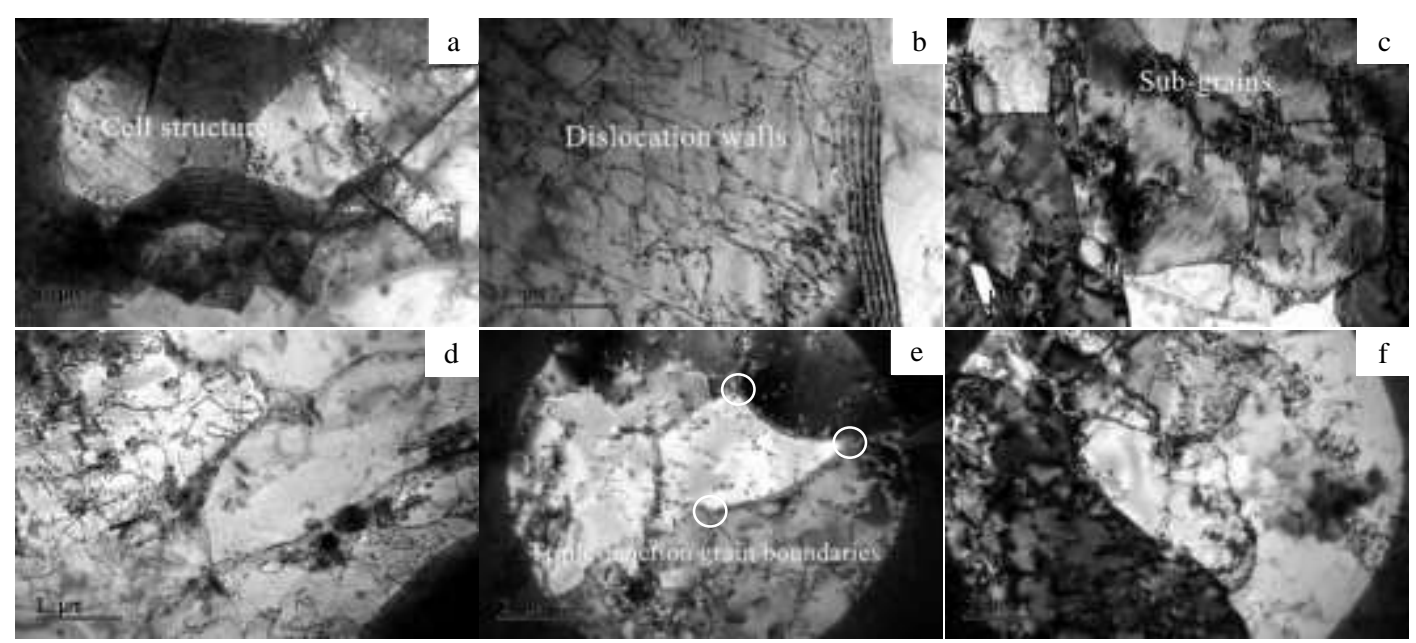

Fig.5 TEM images of sample corresponding to different stages of multi-pass hot deformation in Fig.4: (a) 1-; (b) 1+; (c) 2-; (d) 2+; (e) 3+; (f) 5-(“1,2" on behalf of the corresponding deformation pass, respectively; '-' : water quenching immediately after each deformation pass; '+': water quenching immediately after the holding time at each deformation pass)

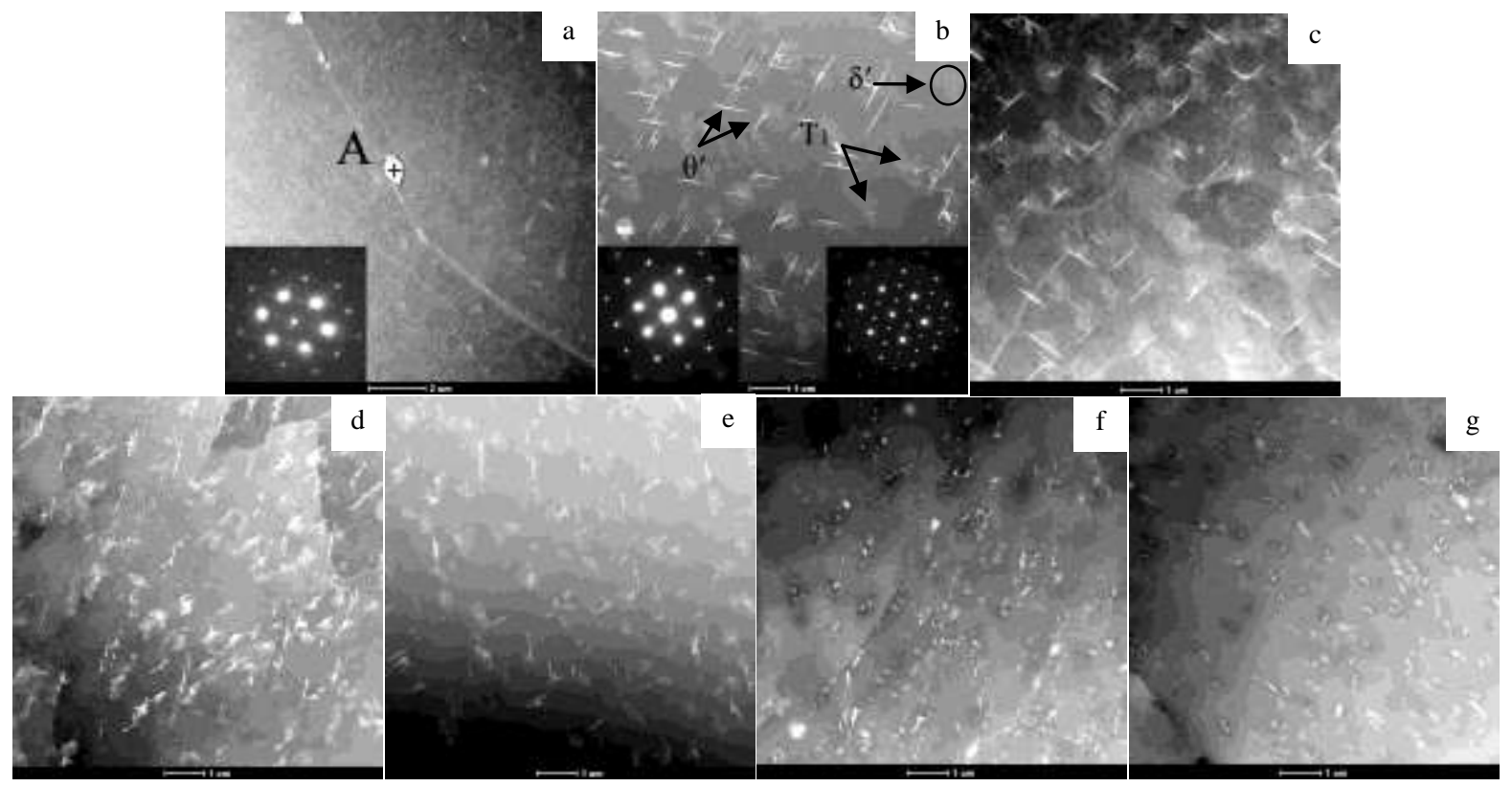

Fig.6 STEM images and SAED (selected area electro diffraction) pattern along the $[110]_{\mathrm{Al}}$ axis of the original sample without compression and deformed sample corresponding to different stages of multi-pass hot deformation in Fig.4: (a) STEM images of original sample (homogenized at $460{ }^{\circ} \mathrm{C} / 20 \mathrm{~h}$ followed by $525^{\circ} \mathrm{C} / 24 \mathrm{~h}$ then cooled in air), together with a SAED model in insert; (b) 1-; (c) 1+; (d) 2-; (e) $2+$; (f) $3+$; (g) 5-(“1, 2, 3, 5” on behalf of the corresponding deformation pass, respectively; '-' : water quenching immediately after each deformation pass; '+': water quenching immediately after the holding time at each deformation pass)

Table 2 Chemical composition of massive particles in Fig.6a

\begin{tabular}{ccc}
\hline Point & Element & Content/at\% \\
\hline \multirow{3}{*}{$\mathrm{A}$} & $\mathrm{Al}$ & 85.97 \\
& $\mathrm{Cu}$ & 06.03 \\
& $\mathrm{Mn}$ & 06.50 \\
& $\mathrm{Fe}$ & 00.12 \\
\hline
\end{tabular}

(Fig.6b, 6c). B. M. Gable ${ }^{[20]}$ reported that the growth of each large $\mathrm{T}_{1}$ plate consumed the copper and lithium from the adjacent region, causing the number and density decrease of $\delta^{\prime}$ phase. However, there was no obvious change in size of the $\delta^{\prime}-\left(\mathrm{Al}_{3} \mathrm{Li}\right)$ phase. Besides, the obvious static softening at the interval between the first and second pass (Fig.5a, 5b), decreases flow stress at the second 
pass(Fig.4). With the increasing of strain, sub-grains structure is more complete due to dynamic softening and static softening, as shown in Fig.5b 5f. What's more, partial $\theta^{\prime}$ and $\mathrm{T}_{1}$ are gradually dissolved into the alloy matrix, resulting in the size of $\theta^{\prime}$ and $\mathrm{T}_{1}$ decrease, as shown in Fig.6b 6g. The fine size of the precipitates is conducive to prevent the movement of the dislocation. Although the static softening between the deformation pass is beneficial to the dynamic softening, the precipitation strengthening effect is stronger after the second pass. Finally, flow stress of multi-pass gradually increases and approaches the single-pass deformation (Fig.4). It is concluded that the change of the flow stress is influenced by dynamic softening, static softening and dynamic precipitation.

\section{Conclusions}

1) During double-pass hot deformation, the extension of interval time between two passes is conductive to promoting static softening. It is possible to control the grain size in the test alloy by changing strain rate at different deformation stages.

2) During multi-pass hot deformation process, static softening between the deformation pass is beneficial to dynamic softening, vice versa.

3) Dynamic precipitation of $T_{1}$ and $\theta^{\prime}$ phase is observed during multi-pass deformation process $\left(T=420{ }^{\circ} \mathrm{C}, \dot{\varepsilon}=0.1\right.$ $\left.\mathrm{s}^{-1}\right)$. In the initial stage of deformation, strain-induced dislocations provide the nucleation site for $\theta^{\prime}$ and $\mathrm{T}_{1}$ phase, promoting their precipitation and coarsening. With increasing of strain, the size of the precipitates $\mathrm{T}_{1}$ and $\theta^{\prime}$ phase decreases and then tends to be stable, and the density of $\delta^{\prime}$ phase decreases. Flow stress of the test alloy during multi-pass hot deformation is influenced by dynamic softening, static softening and dynamic precipitation.

\section{References}

1 Pasang T, Symonds N, Moutsos S et al. Engineering Failure Analysis $[\mathrm{J}], 2012,22: 166$
2 Rokni M R, Zarei-Hanzaki A, Roostaei Ali A et al. Metallurgical Materials Transactions A[J], 2012, 43(9): 3325

3 Zhang Fei, Shen Jian, Yan Xiaodong et al. Transactions of Nonferrous Metals Society of China[J], 2014, 24(3): 798

4 Li Bo, Pan Qinglin, Yin Zhimin. Materials Science and Engineering $A[\mathrm{~J}], 2014,614: 199$

5 Yin Hao, Li Hongying, Su Xiongjie et al. Materials Science and Engineering $A[\mathrm{~J}], 2013,586: 115$

6 Zhang Saifei, Zeng Weidong, Yang Wenhua et al. Materials and Design[J], 2014, 63: 368

7 Ritsuko Yoshimura, Toyohiko J Konno, Eiji Abe et al. Acta Materialia[J], 2003, 51: 4251

8 Yan Liangming, Shen Jian, Li Zhoubing et al. The Chinese Journal of Nonferrous Metals[J], 2012, 22(4): 1013 (in Chinese)

9 Zhang Fei, Shen Jian, Yan Xiaodong et al. Acta Metallurgica Sinica[J], 2014, 50(6): 691 (in Chinese)

10 Xun Y, Tan M J. Materials Characterization[J], 2004, 52: 187

11 Terrones L A H, Monteiro S N. Materials Characterization[J], 2007, 58(2): 156

$12 \mathrm{Mu} \tilde{\boldsymbol{n}}$ oz-Morris M A, Gutierrez-Urrutia I, Calderon $\mathrm{N}$ et al. Materials Science and Engineering A[J], 2008, 492(1-2): 268

13 Jiang Na, Li Jinfeng, Zheng Ziqiao et al. Rare Metal Material and Engineering [J], 2007, 36(6): 949 (in Chinese)

14 Lin Y C, Liu Ge, Chen Mingsong et al. Journal of Materials Processing Technology[J], 2009, 209: 4611

15 Taku Sakai. Journal of Materials Processing Technology[J], 1995, 53(1-2): 349

16 Mirzadeh H, Najafizadeh A. Materials and Design[J], 2010, 31: 1174

17 Jiang Fulin, Zhang Hui, Li Luoxing et al. Materials Science and Engineering $A[\mathrm{~J}], 2012,552: 269$

18 Kwon O, DeArdo A J. Acta Metall[J], 1990, 387(38): 41

19 Noble B, Thompson G E. Met Sci[J], 1972, 6: 167

20 Gable B M, Csontos A A, Starke J E A. Journal of Light Metals[J], 2002, 2: 65

\section{$\mathrm{Al}-\mathrm{Cu}-\mathrm{Li}$ 合金多道次热变形过程中的力学行为与微观组织演化}

杨胜利, 沈 健, 李锡武, 闰晓东, 张永安, 李志辉, 黄树辉, 熊柏青 (北京有色金属研究总院 有色金属材料制备加工国家重点实验室，北京 100088)

摘 要: 对 Al-2.5Cu-1.58 Li-0.3Mn-0.12Zr-0.06Mg-0.05Ti (质量分数, \%)合金进行连续、不连续、双道次和多道次热压缩, 研究其力学行为 和微观组织演化。采用 Gleeble-1500 试验机对合金进行热变形, 变形温度为 $420{ }^{\circ} \mathrm{C}$, 应变速率分别为 $0.001,0.1$ 和 $10 \mathrm{~s}^{-1}$, 对合金不同热 变形阶段进行 EBSD 和 TEM 分析。双道次热压缩表明, 道次间隔时间的延长有利于促进静态软化。通过改变变形过程中的应变速率，可 控制合金的晶粒尺寸。多道次热变形过程中, 道次间的静态软化促进动态软化, 反之亦然。在多道次热变形过程中 $\left(T=420{ }^{\circ} \mathrm{C}, \dot{\varepsilon}=0.1 \mathrm{~s}^{-1}\right)$ 出现 $\mathrm{T}_{1}$ 和 $\theta^{\prime}$ 相动态析出。变形初始阶段, 应变诱导的位错为 $\mathrm{T}_{1}$ 和 $\theta^{\prime}$ 相提供形核位置, 促进它们的析出和粗化。随应变的增加, $\mathrm{T}_{1}$ 和 $\theta^{\prime}$ 相尺寸减小并趋于稳定, $\delta^{\prime}$ 相密度降低。试验合金多道次热变形过程中的流变应力受动态软化、静态软化和动态析出综合影响。 关键词：流变应力; 动态软化; 静态软化; 动态析出

作者简介: 杨胜利, 男, 1986 年生, 博士生, 北京有色金属研究总院有色金属材料制备加工国家重点实验室, 北京 100088 , 电话: 010-82241172, E-mail: bravictors@126.com 